\title{
A comparative study of some hematological parameters of broiler and indigenous breeds of poultry
}

\author{
Muneer, M. ${ }^{1}$, M. Bilal ${ }^{2 *}$ and A. Ditta ${ }^{1}$ \\ ${ }^{I}$ Department of Zoology, University of Central Punjab, Lahore, Pakistan. \\ ${ }^{2}$ Department of Zoology, Faculty of Science \& Technology, Virtual University of Pakistan, Rawalpindi-46300, \\ Pakistan.
}

\begin{abstract}
The investigational trials were conducted on day-old, total ninety chicks of broilers and indigenous (IND) poultry breeds in controlled conditions to analyze some hematological parameters. Water and basal diet were provided $a d$ libitum. The experiment was carried out for 20 weeks. A total of 40 blood samples 20 for each breed were collected in a randomized manner through a brachial cut at the end of the trial. Hematological parameters, i.e., $\mathrm{RBCs}\left(10^{6} / \mu \mathrm{l}\right)$, WBCs $\left(10^{3} / \mu \mathrm{L}\right)$, Lymphocytes $\left(10^{3} / \mu \mathrm{L}\right)$, Monocytes $\left(10^{3} / \mu \mathrm{L}\right)$, PLTs $\left(10^{3} / \mu \mathrm{L}\right), \mathrm{Hb}(\mathrm{g} / \mathrm{dL}), \mathrm{Ht}(\%), \mathrm{MCV}(\mathrm{fL}), \mathrm{MCH}$ $(\mathrm{pg})$, and MCHC $(\mathrm{g} / \mathrm{dL})$ were analyzed. Two-tailed Student t-test was applied to compare the means $(\mathrm{p}<0.05)$ of hematological parameters of both breeds. The findings exhibited that total RBCs, PLTs, and Hb concentration, were considerably higher $(\mathrm{p}<0.05)$ in IND chickens than broilers. On the other hand, the total WBCs, Lymphocytes, and Monocytes were remarkably higher $(\mathrm{p}<0.05)$ in broilers than the IND breed. However, no statistically important distinction ( $\mathrm{p}>0.05$ ) noted in both breeds in $\mathrm{Ht}, \mathrm{MCV}, \mathrm{MCH}$, and MCHC parameters.
\end{abstract}

Keywords: Broilers; Hematological Analysis; Hematological Parameters; Indigenous Chickens.

\section{Introduction}

The tremendous increment in the world population has caused the severe depletion of feeding resources and a tremendous increase in poverty. In very recent times, the poultry industry is striving to fulfill the demand for provision of high nutritional white meat (Ebrahimi et al., 2013), plummeting poverty and scarcity via green jobs generation, and eventually raise everyday comforts (Gueye, 2009; Mengesha, 2013). Much attention has been focused on the poultry industry for its compatibility with dietary legislation with religious and ethnic groups (Shah et al., 2021).

For utilization purposes, chickens are categorized into single-purpose- layers and broilers, dual-purpose- for eggs and meat, and multipurpose- for general use in daily life

\footnotetext{
*Corresponding author: Muhammad Bilal,

Email: bilalvu4@gmail.com

Received: October 3, 2021; Accepted: November 9, 2021;

Published online: December 1, 2021.

(C) Published by South Valley University.

This is an open access article licensed under (c)
}

including commercial broiler and layer chickens (Mustafa and Muneer, 2013). Multiuse indigenous (IND) rural chickens can produces eggs and meat, also yield ornamental feathers as an amusing aspect (Halima et al., 2007). Freeranging IND village chickens possess high genomic diversity, are usually sturdier, diseaseresistant, have a long lifespan, and give useful services to the social and cultural life (Msoffe et al., 2005; Mapiye et al., 2008; Padhi, 2016; Fathi et al., 2017). IND chickens are essential contributors to human sustenance diversification by assuming a pivotal role in production (Mtileni et al., 2009), in religious rituals, give pleasure wellspring as game and presentation as comradeship (Larson et al., 2012).

Due to fast growth and short harvesting time, broiler farming has developed much faster than IND chicken farming around the world. Broiler chickens are typically raised in unfertile areas with heightened stocking concentrations resulting in various health issues (Bessei, 2006). 
It is linked to elevated development rates, small levels of workouts, and elevated body weights (Knowles et al., 2008; Reiter and Bessei, 2009). In Pakistan, native and broiler chickens play a noteworthy role in eliminating the breach between daily demand and animal protein supply.

Blood hemato-biochemical parameters are used to assess an animal's nutritional and clinical health conditions (Olorede and Longe, 2000; Aderemi, 2004; Khan and Zafar, 2005; Doyle, 2006; Olafedehan et al., 2010). These profiles give us significant data for the analysis of avian immunology, pathology, environmental, and/or pathological stresses, and bird health (Adeyemi et al., 2000; Togun et al., 2007; Bonadiman et al., 2009; Afolabi et al., 2011), which are used as to improve the animal's health status (Ladokun et $a l ., 2008)$. It is extensively used in birds like chicken (Adeyemi et al., 2000), Helmeted guineafowl-Numida meleagris (Onyeanusi, 2007), Pigeon-Columba livia domestica (Pavlak et al., 2005), Japanese quail-Coturnix japonica (Arora, 2010), and Bronze turkey-Meleagris gallopavo (Schmidt et al., 2009), etc.

The hereditary traits, nutritional, physiological, ecological relationships, and environmental characteristics have a significant impact on the hemato-biochemical profiles of different breeds of poultry (Ovuru and Ekweozor, 2004; Subhadarsini and Silpa, 2020). These circumstances are of utmost importance in animal selection that is hereditarily resilient to specific diseases and unfavorable environmental circumstances (Isaac et al., 2013; Mmereole, 2008). As stated by Isaac et al. (2013), an animal having a good blood profile may exhibit excellent performance. Hence, current exploratory trials were carried out for the difference and comparison haemato-biochemical parameters of broiler and IND breeds of poultry.

\section{Materials and methods}

\subsection{Experimental Birds}

This research study was deliberated from January to May 2021 at the University of Central Punjab, Lahore, Pakistan. Experimental IND chicks were acquired from a local market of 27/SP village, District Pakpattan, and broiler chicks were taken from a poultry farm at Pakpattan city. These chickens were housed under their conventional feeding habits and environmental factors (Subhadarsini and Silpa, 2020).

Uniformity in the management of chicks was maintained. Both flocks were offered with the appropriate amount of commercially available poultry mash and crumble feeds and replenished twice daily. Potable fresh water was provided ad libitum during whole study retro. After brooding, feeders and drinkers were fixed in such a way that birds can continuously eat and drink.

\subsection{Blood Sampling}

In the $20^{\text {th }}$ week of the investigational study (Khawaja et al., 2016; Parveen et al., 2017), sampling was done using $5 \mathrm{~mL}$ Syringes, 22 Gauge x 1-1/2 Inch Needles. Before ejaculating blood, plumes were removed and ethanol (70\%) was employed with cotton swab to distend the wing vein (Duah et al., 2020). Samples were amassed from the live chickens by piercing the lower side of brachial vein of the wing with full consideration of animal welfare.

In each sample collection, a sterilized syringe with a needle was used and then discarded it. A total of 40 blood samples including broilers $(n=20)$ and IND $(n=20)$ were collected in a randomized design. The samples were instantly transferred into $3 \mathrm{ml}$ of glass vials pretreated with Tripotassium Ethylenediamine Tetraacetic Acid ( $\mathrm{K}_{3}$ EDTA) and meticulously quiver to mix the sample with the $\mathrm{K}_{3} \mathrm{EDTA}$. It inhibits blood coagulation. Blood samples were 
labeled properly and instantly placed in a deep freezer to prevent degradation of the samples.

\subsection{Haematological Analysis}

The hemato-biochemical analysis was carried out deliberately to examine the hematological values of RBCs, WBCs, Lymphocytes, Monocytes, Platelets (PLTs), Hemoglobin Concentration ( $\mathrm{Hb})$, Hematocrit $(\mathrm{Ht}), \mathrm{MCV}, \mathrm{MCH}$, and MCHC (Abdulwahid and Oleiwi, 2021) as shown in Table 1.

Neubauer Hemocytometer was used for determining the total number of RBCs and WBCs (Abuoghaba, 2018). Lymphocytes and Monocytes were counted using DLC standard procedures defined by Wakenell (2010). PLT counting was done while performing DLC by using Compound Microscope (Mayengbam et al., 2020). Sahli's Haemoglobinometer was employed to measure $\mathrm{Hb}$ concentration (Patil et al., 2013). Ht was calculated using the Microhematocrit Capillary Tube, centrifuged at 10,000 RPM for 5 minutes (López et al., 2018; Duah et al., 2020).

Following formulae were used to evaluate the $\mathrm{MCV}, \mathrm{MCH}$, and $\mathrm{MCHC}$ values (Odunitan-Wayas et al., 2018);

$\operatorname{MCV}(\mathrm{fL})=\frac{\mathrm{Ht}(\%) \times 10}{\mathrm{RBC}(\text { millions } / \mu \mathrm{L})}$

$\mathrm{MCH}(\mathrm{pg})=\frac{\mathrm{Hb}(\mathrm{g} / \mathrm{dL}) \times 10}{\mathrm{RBC}(\text { millions } / \mu \mathrm{L})}$

$\operatorname{MCHC}(\mathrm{g} / \mathrm{dL})=\frac{\mathrm{Hb}(\mathrm{g} / \mathrm{dL}) \times 100}{\mathrm{Ht}(\%)}$

\subsection{Statistical Analysis}

The hemato-biochemical constraints were denoted as Mean \pm SE in both breeds, using the latest MS Excel Spreadsheet 2019. A two-tailed Student t-test was applied to compare the means $(p<0.05)$ of hematological parameters of both breeds (Alam et al., 2020). "Two-Sample
Assuming Equal Variances" was used as a type in employing t-test.

\section{Results and discissions}

Hematological parameters, i.e., RBC $\left(10^{6} / \mu 1\right)$, WBC $\left(10^{3} / \mu \mathrm{L}\right), \quad$ Monocytes $\left(10^{3} / \mu \mathrm{L}\right)$, Lymphocytes $\left(10^{3} / \mu \mathrm{L}\right), \quad$ PLTs $\left(10^{3} / \mu \mathrm{L}\right), \mathrm{Hb}$ $(\mathrm{g} / \mathrm{dL}), \mathrm{Ht}(\%), \mathrm{MCV}(\mathrm{fL}), \mathrm{MCH}(\mathrm{pg})$, and MCHC $(\mathrm{g} / \mathrm{dL})$, were measured and listed in Table 1.

\subsection{Total RBCs (Red Blood Cells)}

The findings of the present study depicted different numbers of RBCs in both breeds, as shown in Table 1 . The RBC $\left(10^{6} / \mu \mathrm{l}\right)$ values vary from $3.55 \pm 0.07$ to $2.49 \pm 0.05$ for IND and broilers respectively. The RBCs values were statistically greater $(\mathrm{p}<0.05)$ in IND as compared to broilers. Similar studies by Subhadarsini and Silpa (2020) enumerated the almost same amount of RBCs in both breeds. By contrast, these outcomes contradict the present study.

Parveen et al. (2017) found the amplification of $\mathrm{RBCs}$ and $\mathrm{Hb}$ with the development and growth of chicks. That fulfills the $\mathrm{O}_{2}$ requirements of the growing chicks. $\mathrm{RBCs}$ serve as transporters of $\mathrm{O}_{2}$ and $\mathrm{CO}_{2}$ through $\mathrm{Hb}$ (Chineke et al., 2006). Therefore, a lower number of RBCs possess a lower concentration of $\mathrm{Hb}$ which leads to less amount of the $\mathrm{O}_{2}$ that would be transported to the tissue and the $\mathrm{CO}_{2}$ level that returns to the lungs (Soetan et al., 2013; Ugwuene, 2011).

\subsection{Total WBCs (White Blood Cells)}

Presented results of this study shows that total WBCs $\left(10^{3} / \mu \mathrm{L}\right)$ ranges from $80.33 \pm 2.47$ to $18.82 \pm 1.39$ for broiler and IND breeds, respectively. The WBC values were higher $(\mathrm{p}<0.05)$ in broiler in comarison to IND chickens. Previous studies concluded different results. 
Different breeds of poultry exhibited substantial and noteworthy distinctions except WBCs.

The main functions of WBCs combat against inflammation defend against antigens, microorganisms, unfamiliar particles, and produce or at least transport and distribute immunoglobins in the immune reaction. So, organisms with low WBC numbers are at high risk of infectious diseases (Soetan et al., 2013) and also improve adaptations to the harsh environment and resistance against diseases (Iwuji and Herbert, 2012; Kabir et al., 2011). Any type of emotional or physical stress can also cause WBC count to dwindle.

\subsection{Total Lymphocyte Count}

We found considerably different number of Lymphocytes in both breeds. The total number of Lymphocytes $\left(10^{3} / \mu \mathrm{L}\right)$ varies from $70.83 \pm 2.17$ to $11.98 \pm 0.94$ for broiler and IND breeds, respectively. The Lymphocyte values were statistically greater $(\mathrm{p}<0.05)$ in broilers than IND chickens. Alam et al. (2020) conducted a study on hemato-biochemical and serum profiles of broiler and IND breeds of poultry. He also found considerably lower hemato-biochemical parameters of IND chickens as compared to broiler.

\subsection{Total Monocyte Count}

The total number of monocytes $\left(10^{3} / \mu \mathrm{L}\right)$ were $5.13 \pm 0.13$ to $3.21 \pm 0.18$ for broiler and IND breeds, respectively. The total number of monocytes was substantially distinct in both breeds, statistically greater $(\mathrm{p}<0.05)$ in broiler as compared to IND chickens. Even so, Subhadarsini and Silpa (2020) found no noteworthy difference $(p>0.05)$ between monocytes in both breeds broiler and IND breeds. Subsequently, they stated the effect of different feeding habits, environmental factors, and immunity, etc. on the hemato-biochemical profiles of both varieties. These parameters change because of the aforementioned factors.

\subsection{Total PLTs (Platelet Cells)}

The findings demonstrated that Total PLTs $\left(10^{3} / \mu \mathrm{L}\right)$ range from $62.56 \pm 1.43$ to $36.78 \pm 2.66$ for IND and broilers, respectively. This variance was large enough to be statistically important. PLTs values were statistically greater in IND as compared to broilers. Dutta et al. (2013) designed a study on five different varieties of chicken to investigate the hemato-biochemical profiles of different breeds. They found that all hemato-biochemical parameters exhibited substantial and noteworthy distinctions among the different breeds of poultry $(\mathrm{p}<0.01)$.

\subsection{Hb (Hemoglobin) Concentration}

During the present study, we found a statistically pivotal $(\mathrm{p}<0.05)$ difference between $\mathrm{Hb}(\mathrm{g} / \mathrm{dL})$ concentrations of IND and broilers i.e. $11.48 \pm 0.33$ to $7.69 \pm 0.10$, respectively. The $\mathrm{Hb}$ concentration was statistically higher in IND as compared to broilers. Subhadarsini and Silpa (2020) revealed the noteworthy increased $\mathrm{Hb}$ concentration in IND breed and as a consequence of its higher oxygen utilization, it was probably suggested more dynamic than the broiler. The finding suggested that the different breeds have different $\mathrm{Hb}$ concentrations for oxygen consumption, accordingly.

$\mathrm{Hb}$ is a metalloprotein that contains iron, it is an oxygen-transporter protein attached to RBCs of all vertebrates (Sidell and O'Brien, 2006; Etim et al., 2014). The physiological function of $\mathrm{Hb}$ is to deliver $\mathrm{O}_{2}$ into animal tissues to oxidize the consumed food to produce ATP which will be utilized for other biological processes as well as transportation of $\mathrm{CO}_{2}$ out of the animal's body (Omiyale et al., 2012). Low Hb concentration leads to inactivity in chickens (as in broilers). 


\subsection{Ht (Hematocrit) Volume}

The study showed that Ht values in both breeds were not considerably dissimilar $(\mathrm{p}>0.05)$. $\mathrm{Ht}(\%)$ values range from $31.53 \pm 1.60$ to $42.21 \pm 1.71$ for broilers and IND chickens respectively. There was no significant difference observed in both breeds. Ht (PCV) is the \%age of RBCs in the blood. Ht plays a vital role in carrying $\mathrm{O}_{2}$ and absorbed nutrients (Isaac et al.,
2013). A high level of Ht causes a decrease in circulating plasma volume and eventually results in polycythemia. Conversely, Subhadarsini and Silpa (2020) observed remarkably higher $\mathrm{Ht}$ values $(\mathrm{p}<0.001)$ in IND than that of broiler chicken. Khawaja et al. (2016) and Parveen et al. (2017) studied hematological parameters of different, commercial, and single-purpose breeds and claimed that the $\mathrm{RBC}, \mathrm{Hb}$, and $\mathrm{PCV}$ were amplified as the chicks growed.

Table 1. Comparison of Some Hematological Parameters of Broiler and IND Breeds of Poultry

\begin{tabular}{|c|c|c|c|}
\hline \multirow{2}{*}{$\begin{array}{l}\text { Hematological Parameters } \\
\text { RBC }\left(10^{6} / \mu 1\right)\end{array}$} & \multirow{2}{*}{$\begin{array}{l}\text { Different Breeds } \\
\text { In Broiler }\end{array}$} & \multicolumn{2}{|c|}{ Mean \pm SE } \\
\hline & & 2.49 & \pm 0.05 \\
\hline & In IND & 3.55 & \pm 0.07 \\
\hline \multirow{2}{*}{$\mathrm{WBC}\left(10^{3} / \mu \mathrm{L}\right)$} & In Broiler & 80.33 & \pm 2.47 \\
\hline & In IND & 18.82 & \pm 1.39 \\
\hline \multirow{2}{*}{ Lymphocytes $\left(10^{3} / \mu \mathrm{L}\right)$} & In Broiler & 70.83 & \pm 2.17 \\
\hline & In IND & 11.98 & \pm 0.94 \\
\hline \multirow{2}{*}{ Monocytes $\left(10^{3} / \mu \mathrm{L}\right)$} & In Broiler & 5.13 & \pm 0.13 \\
\hline & In IND & 3.21 & \pm 0.18 \\
\hline \multirow[b]{2}{*}{$\operatorname{PLT}\left(10^{3} / \mu \mathrm{L}\right)$} & In Broiler & 36.78 & \pm 2.66 \\
\hline & In IND & 62.56 & \pm 1.43 \\
\hline \multirow{2}{*}{$\mathrm{Hb}(\mathrm{g} / \mathrm{dL})$} & In Broiler & 7.69 & \pm 0.10 \\
\hline & In IND & 11.48 & \pm 0.33 \\
\hline \multirow{2}{*}{$\mathrm{Ht}(\%)$} & In Broiler & 31.53 & \pm 1.60 \\
\hline & In IND & 42.21 & \pm 1.71 \\
\hline \multirow{2}{*}{$\mathrm{MCV}$ (fL) } & In Broiler & 126.75 & \pm 7.50 \\
\hline & In IND & 118.76 & \pm 4.86 \\
\hline \multirow{2}{*}{$\mathrm{MCH}(\mathrm{pg})$} & In Broiler & 31.71 & \pm 0.56 \\
\hline & In IND & 32.29 & \pm 1.08 \\
\hline \multirow{2}{*}{$\mathrm{MCHC}(\mathrm{g} / \mathrm{dL})$} & In Broiler & 25.02 & \pm 1.31 \\
\hline & In IND & 27.19 & \pm 1.70 \\
\hline
\end{tabular}




\section{8. $\mathrm{MCV}, \mathrm{MCH} \& \mathrm{MCHC}$}

The findings exhibited that $\mathrm{MCV}, \mathrm{MCH}$, and MCHC values in both breeds did not considerably varied. MCV values range from $118.76 \pm 4.86$ to $126.75 \pm 7.50$ for IND and broilers respectively. The $\mathrm{MCH}$ values range from $31.71 \pm 0.56$ to $32.29 \pm 1.08$ for broilers and IND chickens respectively. The MCHC values range from $25.02 \pm 1.31$ to $27.19 \pm 1.70$ for broilers and IND chickens respectively. $\mathrm{MCH}$ and $\mathrm{MCHC}$ levels represent blood profile status and decrease with age (Khawaja et al. 2016; Parveen et al. 2017), e.g. lower are anemia indication (Aster, 2004). Previous studies published remarkably higher $\mathrm{MCH}$, and MCV values in IND than that of broiler chickens (Subhadarsini and Silpa, 2020).

\section{Conclusion}

The findings for two different breeds of poultry revealed that two, unlike breeds, have had some substantial changes in some critical blood parameters, while some of which are nonsignificant. The findings exhibited that total RBC $\left(10^{6} / \mu \mathrm{l}\right), \quad$ PLT $\left(10^{3} / \mu \mathrm{L}\right)$, and $\mathrm{Hb} \quad(\mathrm{g} / \mathrm{dL})$ concentration was significantly higher in IND chickens which were $3.55 \pm 0.07,62.56 \pm 1.43$, and $11.48 \pm 0.33$ as compared to broilers, $2.49 \pm 0.05$, $36.78 \pm 2.66,7.69 \pm 0.10$, respectively. The total number of WBC $\left(10^{3} / \mu \mathrm{L}\right)$, Lymphocytes $\left(10^{3} / \mu \mathrm{L}\right)$, and Monocytes $\left(10^{3} / \mu \mathrm{L}\right)$ were significantly higher in broilers which were $80.33 \pm 2.47, \quad 70.83 \pm 2.17$, and $5.13 \pm 0.13$ as compared to IND breed, $18.82 \pm 1.39,11.98 \pm 0.94$, and $3.21 \pm 0.18$, respectively.

However, the findings revealed that the $\mathrm{Ht}(\%), \mathrm{MCV}$ (fL), MCH (pg), and MCHC $(\mathrm{g} / \mathrm{dL})$, values were not statistically different in both breeds. The $\mathrm{Ht}$ values range from $31.53 \pm 1.60$ to $42.21 \pm 1.71$ for broilers and IND chickens respectively. The MCV values range from $118.76 \pm 4.86$ to $126.75 \pm 7.50$ for IND and broilers respectively. The $\mathrm{MCH}$ values range
The comparative hematological study of IND and broiler chickens can determine the health status for diagnosing and treating birds properly. In different regions of the world, the hemato-biochemical constraints of different breeds of poultry are varied. Even different breeds, strains and gender with different feeding habits and feed supplements have different hematological profiles (Turcu et al., 2011; Beski and Al-Sardary, 2015; Sugiharto et al., 2018; Alam et al., 2020; Adewole et al., 2021; Oyedele et al., 2021). Moreover, different microorganisms (Alwaleed et al., 2021; Maoba et al., 2021), some floral parts, essential oils and phytochemicals (Abdulazeez et al., 2016; Abuoghaba, 2018; Iqbal and Bayram, 2021; Sunu et al., 2021) have been found to have remarkable impacts on serum and hemato-biochemical profiles of chickens.

from $31.71 \pm 0.56$ to $32.29 \pm 1.08$ for broilers and IND chickens respectively. The MCHC values range from $25.02 \pm 1.31$ to $27.19 \pm 1.70$ for broilers and IND chickens respectively. Thus, in $\mathrm{Ht}(\%)$, $\mathrm{MCV}$ (fL), $\mathrm{MCH}$ (pg), and MCHC (g/dL), there was no significant distinction noted in both breeds.

\section{Acknowledgements}

We would like to express sincere thanks to Dr. Hafiz Mazhar Hussain, Mr. Muhammad Imran Siddique, Mr. Muhammad Ahmad and anonymous reviewers for their support during this work.

\section{References}

Abdulazeez, H., Adamu, S., Igwebuike, J., Gwayo, G. and Muhammad, A. (2016) 'Haematology and serum biochemistry of broiler chickens fed graded levels of Baobab (Adansonia digitata L.) seed meal' IOSR Journal of Agriculture and Veterinay Science (IOSR-JAVS), 9, pp. 48-53.

Abdulwahid, M.T. and Oleiwi, A.F. (2021) 'Ameliorating effects of silymarin 
against mycotoxin and its effect on some production and hematological parameters of broilers' Journal of Genetic and Environmental Resources Conservation, 9, pp. 207-214.

Abuoghaba, A.A.K. (2018) 'Impact of bee pollen supplementation on productive performance, some hematological parameters, blood constituents and semen physical characteristics of Sinai chickens' Egyptian Poultry Science Journal, 38, pp. 621-635.

Aderemi, F. (2004) 'Effects of replacement of wheat bran with cassava root sieviate supplemented or unsupplemented with enzyme on the haematology and serum biochemistry of pullet chicks' Tropical Journal of Animal Science, 7, pp. 147153.

Adewole, F., Egbeyale, L., Ekunseitan, D., Bello, K., Lala, O. and Famakinde, S. (2021) 'Effect of strain and sex on haematological and serum biochemical indices of tropical indigenous chickens' Nigerian Journal of Animal Production, 48, pp. 18-26.

Adeyemi, O., Fasina, O. and Balogun, M. (2000) 'Utilization of Full-Fat Jatropha Seed in Broiler Diet: Effect on Haematological Parameters and Blood Chemistry' Proceedings of the 25th Conference of Nigerian Society for Animal Production held at Michael Okpara University of Agriculture, Umudike. pp. 19-23.

Afolabi, K.D., Akinsoyinu, A.O., Abdullah, A.R.O., Olajide, R. and Akinleye, S.B. (2011) 'Haematological parameters of the Nigerian local grower chickens fed varying dietary levels of palm kernel cake' Poljoprivreda, 17, pp. 74-78.

Alam, M., Ohid Ullah, M., Umme F.M.S. and Shahidul I.M. (2020) 'Broiler and Indigenous Chickens: A Comparison through Biochemical Parameters'
International Journal of Sustainable Agricultural Research, 7, pp. 228-233.

Alwaleed, E.A., El-Sheekh, M., Abdel-Daim, M.M. and Saber, H. (2021) 'Effects of Spirulina platensis and Amphora coffeaeformis as dietary supplements on blood biochemical parameters, intestinal microbial population, and productive performance in broiler chickens' Environmental Science and Pollution Research, 28, pp. 1801-1811.

Arora, K.L. (2010) 'Differences in hemoglobin and packed cell volume in blood collected from different sites in Japanese Quail (Coturnix japonica)' International Journal of Poultry Science, 9, pp. 828830.

Aster, J. (2004) 'Anaemia of diminished erythropoiesis' Robbins and Cotran pathologic basis of disease, pp. 638-649.

Beski, S. and Al-Sardary, S (2015) 'Effects of dietary supplementation of probiotic and synbiotic on broiler chickens hematology and intestinal integrity' International Journal of Poultry Science, 14, pp. 31.

Bessei, W. (2006) 'Welfare of broilers: a review' World's Poultry Science Journal, 62, pp. 455-466.

Bonadiman, S., Stratievsky, G., Machado, J., Albernaz, A., Rabelo, G. and Damatta, R. (2009) 'Leukocyte ultrastructure, hematological and serum biochemical profiles of ostriches (Struthio camelus)' Poultry science, 88, pp. 2298-2306.

Chineke, C., Ologun, A. and Ikeobi, C. (2006) 'Haematological parameters in rabbit breeds and crosses in humid tropics' Pakistan Journal of Biological Sciences, 9, pp. 2102-2106.

Doyle, D. (2006) 'William Hewson (1739-74): the father of haematology' British journal of haematology, 133, pp. 375-381.

Duah, K.K., Essuman, E.K., Boadu, V.G., Olympio, O.S. and Akwetey,W. (2020) 
'Comparative study of indigenous chickens on the basis of their health and performance' Poultry science, 99, pp. 2286-2292.

Dutta, R.K., Islam, M.S. and Kabir, M.A. (2013) 'Haematological and biochemical profiles of Gallus indigenous, exotic and hybrid chicken breeds (Gallus domesticus l.) from Rajshahi, Bangladesh' Bangladesh Journal of Zoology, 41, pp. 135-144.

Ebrahimi, A., Qotbi, A.A.A., Seidavi, A., Laudadio, V. and Tufarelli, V. (2013) 'Effect of different levels of dried sweet orange (Citrus sinensis) peel on broiler chickens growth performance' Archives Animal Breeding, 56, pp. 11-17.

Etim, N., Williams, M.E., Akpabio, U. and Offiong, E.E. (2014) 'Haematological parameters and factors affecting their values' Agricultural Science, 2, pp. 3747.

Fathi, M., Al-Homidan, I., Abou-Emera, O. and Al-Moshawah,

A.

'Characterisation of Saudi native chicken breeds: a case study of morphological and productive traits' World's Poultry Science Journal, 73, pp. 916-927.

Gueye, E. (2009) 'The role of networks in information dissemination to family poultry farmers' World's Poultry Science Journal, 65, pp. 115-124.

Halima, H., Neser, F.W., Van Marle-Koster, E. and De Kock, A. (2007) 'Village-based indigenous chicken production system in north-west Ethiopia' Trop Anim Health Prod, 39, pp. 189-97.

Iqbal, A. and Bayram, I. (2021) 'Effect of onion juice (Allium cepa) on performance, egg quality traits, biochemical and hematological parameters in laying hens' Journal of Animal \& Plant Sciences, 31.

Isaac, L., Abah, G., Akpan, B. and Ekaette, I. (2013) 'Haematological properties of different breeds and sexes of rabbits' Proceedings of the 18th Annual Conference of Animal Science Association of Nigeria, pp. 24-27.

Iwuji, T. and Herbert, U. (2012) 'Haematological and serum biochemical characteristics of rabbit bucks fed diets containing garcimiola kola seed meal' Proceedings of 37th Annual conference of nigerian society for animal production, pp. 87-89.

Kabir, M., Akpa, G., Nwagu, B., Adeyinka, I. and Bello, U. (2011) 'Sexual dimorphism, breed and age characteristics of rabbits in Zaria, Nigeria' Proceedings of the 16th Annual Conference of Animal Science Association of Nigeria, pp. 133-137.

Khan, T.A. and Zafar, F. (2005) 'Haematological study in response to varying doses of estrogen in broiler chicken' International Journal of Poultry Science, 4, pp. 748751.

Khawaja, T., Khan, S.H., Parveen, A. and Iqbal, J. (2016) 'Growth performance, meat composition and haematological parameters of first generation of newly evolved hybridized pure chicken and their crossbred parents' Veterinarski arhiv, 86, pp. 135-148.

Knowles, T.G., Kestin, S.C., Haslam, S.M., Brown, S.N., Green, L.E., Butterworth, A., Pope, S.J., Pfeiffer, D. and Nicol, C.J. (2008) 'Leg disorders in broiler chickens: prevalence, risk factors and prevention' PloS one, 3, pp. 15-45.

Ladokun, A., Yakubu, A., Otite, J., Omeje, J., Sokunbi, O. and Onyeji, E. (2008) 'Haematological and serum biochemical indices of naked neck and normally feathered Nigerian indigenous chickens in a sub humid tropical environment' International Journal of Poultry Science, 7, pp. 55-58.

Larson, G., Karlsson, E.K., Perri, A., Webster, M.T., Ho, S.Y., Peters, J., Stahl, P.W., 
Piper, P.J., Lingaas, F., Fredholm, M., Comstock, K.E., Modiano, J.F., Schelling, C., Agoulnik, A.I., Leegwater, P.A., Dobney, K., Vigne, J.D., Vila, C., Andersson, L. and Lindblad-Toh, K. (2012) 'Rethinking dog domestication by integrating genetics, archeology, and biogeography' Proceedings of the National Academy of Sciences of the $U S$ A, 109, pp. 8878-83.

López, D.P., Huaynate, R.R. and Tananta, R.V. (2018) 'A comparative evaluation of the hematological parameters, biochemical profile and chemical composition of eggs of creole and Hy-line Brown laying hens' Livestock Research for Rural Development, 30.

Maoba, S., Ogbuewu, I., Oguttu, J. and Mbajiorgu, C. (2021) 'Haematological profiles of indigenous Boschveld chickens on probiotic-yeast (Saccharomyces cerevisiae) supplementation' Comparative Clinical Pathology, pp. 1-7.

Mapiye, C., Mwale, M., Mupangwa, J., Chimonyo, M., Foti, R. and Mutenje, M. (2008) 'A research review of village chicken production constraints and opportunities in Zimbabwe' AsianAustralasian Journal of Animal Sciences, 21, pp. 1680-1688.

Mayengbam, P., Tolenkhomba, T. and Ali, M.A. (2020) 'Blood cell morphometry and leukocyte-thrombocyte profile of indigenous chicken Sikhar of Mizoram' Indian Journal of Animal Sciences, 90.

Mengesha, M. (2013) 'Biophysical and the socioeconomics of chicken production' African Journal of Agricultural Reseearch, 7.

Mmereole, F. (2008) 'The effects of replacing groundnut cake with rubber seed meal on the haematological and serological indices of broilers' International Journal of Poultry Science, 7, pp. 622-624.

Msoffe, P.L., Mtambo, M.M., Minga, U., JuulMadsen, H. and Gwakisa, P. (2005) 'Genetic structure among the local chicken ecotypes of Tanzania based on microsatellite DNA typing' African Journal of biotechnology, 4, pp. 768-771.

Mtileni, B., Muchadeyi, F., Maiwashe, A., Phitsane, P., Halimani, T., Chimonyo, M. and Dzama, K. (2009) 'Characterisation of production systems for indigenous chicken genetic resources of South Africa' Applied Animal Husbandry \& Rural Development, 2, pp. 18-22.

Mustafa, Y.S. and Muneer, M.A. (2013) 'Influence of light on the hematology, lymphoid organs and production of the broilers' Sarhad Journal of Agriculture, 29.

Odunitan-Wayas, F., Kolanisi, U. and Chimonyo, M. (2018) 'Haematological and Serum Biochemical Responses of Ovambo Chickens Fed Provitamin A Biofortified Maize' Brazilian Journal of Poultry Science, 20, pp. 425-434.

Olafedehan, C., Obun, A., Yusuf, M., Adewumi, O., Oladefedehan, A., Awofolaji, A. and Adeniji, A. (2010) 'Effects of residual cyanide in processed cassava peal meals on haematological and biochemical indices of growing rabbits' Proceedings of $35^{\text {th }}$ Annual Conference of Nigerian Society for Animal Production.

Olorede, B. and Longe, O. (2000) 'Effect of replacing palm kernel cake with sheabutter cake on egg quality characteristics, haematology and serum chemistry of laying hens' Nigerian Journal of Animal Production, 27, pp. 19-23.

Omiyale, C., Yisa, A. and Ali-Dunkrah, L. (2012) 'Haematological characteristics of Yankasa sheep fed fonio (Digitaria 
iburua) straw based diets' Proceedings of 37th Annual Conference of Nigerian Society for Animal Production. pp. 8789.

Onyeanusi, B. (2007) 'Calcium and phosphorus levels in Nigerian guinea fowls' International Journal of Poultry Science, 6, pp. 610-611.

Ovuru, S. and Ekweozor, I. (2004) 'Haematological changes associated with crude oil ingestion in experimental rabbits' African Journal of Biotechnology, 3, pp. 346-348.

Oyedele, O., Ajibogun, F., Otunla, T. and Olosunde, A. (2021) 'Haematological, biochemical and histological characteristics of broiler chickens fed graded levels of dry distilled cassava with soluble' Nigerian Journal of Animal Production, 48, pp. 128-139.

Padhi, M.K. (2016) 'Importance of indigenous breeds of chicken for rural economy and their improvements for higher production performance' Scientifica.

Parveen, A., Khan, S.H., Khawaja, T., Iftikhar, N. and Khan, S. (2017) 'Growth performance and haemato-biochemical parameters of different breeds of rural chickens' Journal of World's Poultry Research, 7, pp. 114-122.

Patil, P.J., Thakare, G.V. and Patil, S.P. (2013) 'Variability and accuracy of Sahli's method in estimation of haemoglobin concentration' National Journal of Integrated Research in Medicine, 4, pp. 38-44.

Pavlak, M., Vlahović, K., Jerčić, J., Dovč, A. and Župančić, Ž. (2005) 'Age, sexual and seasonal differences of haematological values and antibody status to Chlamydophila sp. in feral and racing pigeons (Columba livia forma domestica) from an urban environment
(Zagreb, Croatia)' European Journal of Wildlife Research, 51, pp. 271-276.

Peter, K. (2008) 'Underutilized and Underexploited Horticultural Crops' Vol. 04, New India Publishing.

Reiter, K. and Bessei, W. (2009) 'Effect of locomotor activity on leg disorder in fattening chicken' Berliner und Munchener Tierarztliche Wochenschrift, 122, pp. 264-270.

Schmidt, E.M., Paulillo, A.C., Martins, G.R. V., Lapera, I.M., Testi, A.J.P., Junior, L.N., Denadai, J., Fagliari, J.J. and FapespBrazil, B. (2009) 'Hematology of the bronze turkey (Meleagris gallopavo): Variations with age and gender' International Journal of Poultry Science, 8, pp. 752-754.

Shah, S.T., Islam, M.T., Zabin, R., Roy, P.C., Meghla, N.S. and Jahid, I.K. (2021) 'Assessment of novel probiotic strains on growth, hematobiochemical parameters, and production costs of commercial broilers in Bangladesh' Veterinary World, 14, pp. 97.

Sidell, B.D. and O'brien, K.M. (2006) 'When bad things happen to good fish: the loss of hemoglobin and myoglobin expression in Antarctic icefishes' Journal of Experimental Biology, 209, pp. 17911802.

Soetan, K., Akinrinde, A. and Ajibade, T. (2013) 'Preliminary studies on the haematological parameters of cockerels fed raw and processed guinea corn (Sorghum bicolor)' Proceedings of 38th Annual Conference of Nigerian Society for Animal Production, pp. 49-52.

Subhadarsini, M. and Silpa, M. (2020) 'Comparative haematology and biochemical parameters of Indigenous broiler chicken' International Journal of Scientific Technology Research, 9, pp. 972-978. 
Sugiharto, S., Yudiarti, T., Isroli, I., Widiastuti, E. and Wahyuni, H.I. (2018) 'Hematological parameters and selected intestinal microbiota populations in the Indonesian indigenous crossbred chickens fed basal diet supplemented with multi-strain probiotic preparation in combination with vitamins and minerals' Vet World, 11, pp. 874-882.

Sunu, P., Sunarti, D., Mahfudz, L.D. and Yunianto, V.D. (2021) 'Effect of synbiotic from Allium sativum and Lactobacillus acidophilus on hematological indices, antioxidative status and intestinal ecology of broiler chicken' Journal of the Saudi Society of Agricultural Sciences, 20, pp. 103-110.

Togun, V., Oseni, B., Ogundipe, J., Arewa, T., Hammed, A., Ajonijebu, D. and Mustapha, F. (2007) 'Effects of chronic lead administration on the haematological parameters of rabbits-a preliminary study' Proceedings of the 41st Conferences of the Agricultural Society of Nigeria.

Turcu, D., Oporanu, M., Grigorescu, P. and Roman, M. (2011) 'Studies on hematological parameters in broiler chickens treated with 50\% Amoxidem' Medicamentul Veterinar.

Ugwuene, M. (2011) 'Effect of dietary palm kernel meal for maize on the haematological and serum chemistry of broiler turkey' Nigerian Journal of Animal Science, 13, pp. 93-103.

Wakenell, P. (2010) 'Hematology of chickens and turkeys' Schalm's Veterinary Hematology. Sixth Edition. WileyBlackwell, pp. 967-958. 